performed in six of the cases with histological changes very similar to those seen in chlorpromazine-induced jaundice. The laboratory findings were a normal or only slightly raised alkaline phosphatase value and high transaminase levels. Certain features in the history were present in several cases: two had suffered from icterus and pruritus gravidarum, and this should be regarded as a contraindication to the use of contraceptive pills. The widespread use of oral contraceptives leads us to the supposition that this cause for jaundice is sometimes overlooked.
REFERENCES

Adlercreutz, H. (1964). Nord. med., 72, 1004

Bakke, J. L. (1965). Brit. med. F., 1, 631.

Cullberg, G. Lundström Re. and Stenram, U. (1965). Ibid. $1,695$.

Eisalo, A., Järvinen, P. A., and Luukkainen, T. (1964). Ibid., 2, 426 Eisalo, A., Jarvinen, ${ }^{2}$. A., and Luukkaine

Ikonen, E. (1964). Acta obstet. gynec. scand., 43, Suppl. No. 5.

Larsson-Cohn, U. (1965). Brit. med. Y., 1, 1414.

Sotaniemi, E., Kreus, K. E., and Scheinin, T. M. (1964). Ibid., 2, 1264

Stoll, B. A., Andrews, J. T., Motteram, R., and Upfill, J. (1965). Ibid., 1, 723 .

Swyer, G. I. M., and Little, V. (1965). Ibid., 1, 1412.

Zimmerman, H. J. (1963). Ann. N.Y. Acad. Sci., 104, 954.

\title{
Thirst Fever, with a Characteristic Temperature Pattern in Infants in Kuwait
}

\author{
YEHIA SHAKER,* M.D., D.C.H
}

Brit. med. F., 1966, 1, 586-588

The importance of water metabolism in infancy and childhood is well recognized. The high metabolic rate of infants as compared with that of adults, the relative excess of their bodywater with a greater daily turnover, as well as the immaturity of their renal function, explain the increased need for water In this age-group and the marked intolerance to water-deprivation. A slight change in the fluid intake, though negligible In an adult, may be serious in a little child with a small total fluid volume and a fairly narrow limit of variability (Hill, 1954).

Fever due to water-deprivation is well known in the newborn. In older infants it is rather rare but sometimes creates diagnostic problems. It may, however, occur in hot climates. In Greece, Choremis et al. (1959) described cases in which infants had an irregular prolonged fever as the only symptom

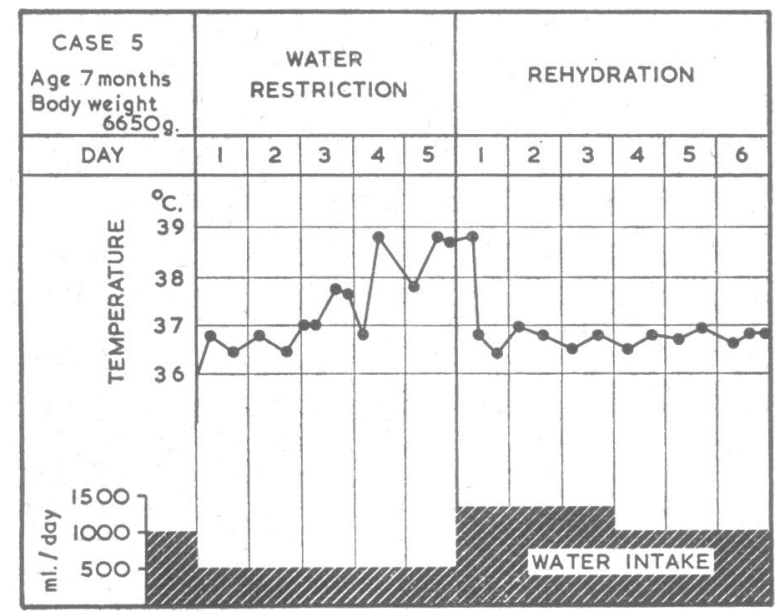

FIG. 1.-Experimentally induced thirst fever and its correction by rehydration (after Choremis et al., 1959). Reproduced by permission, from Helvetica paediatrica acta.

of inadequate water intake, occurring particularly during summer. They also produced such a fever experimentally in infants (Fig. 1).

Thirst fever is due to a relative or an absolute lack of water, resulting in an inadequate reduction of heat. It can therefore occur when the water intake is not sufficient for the needs of

* From the Paediatric Department, Al Sabah Hospital, Kuwait. the infant or when its food is too rich in calories or in proteins and it is not getting any extra water. Holliday and Segar (1957) have estimated that for every gramme of protein given in excess of the minimum requirement $20 \mathrm{ml}$. of extra water is needed to excrete the products of protein catabolism in a larger volume of urine. Increased salt intake has also been described as a cause of fever (Finkelstein, 1938 ; Levesque and Bastin, 1949).

The diagnosis of fever due to water-deprivation is not always easy. It should be based on a careful history, the lack of any other abnormal clinical or laboratory findings, the failure of the infant to respond to any kind of drug treatment, and finally the subsidence of the fever after administration of extra water alone.

This paper presents a clinical variety of thirst fever with a characteristic temperature pattern.

\section{Material and Results}

During the past few years some cases have been referred to the paediatric consultation clinic because of a prolonged pyrexia of unknown origin, most of the patients having already received various kinds of medical treatment without improvement.

Seventeen such patients (10 males and 7 females) were studied (see Table). Fifteen were followed up as out-patients; the other two were admitted to hospital. Their ages ranged from 3 to 10 months with one exception, a male infant aged 13 months. Only one infant was a Kuwaiti ; the rest were of other nationalities. All the cases presented during the hot humid season. The main presenting feature was a pyrexia of long duration, varying between 12 and 68 days. All the infants except one showed a similar unusual pattern of fever-high (ranging from 39 to $40.8^{\circ} \mathrm{C}$. per rectum) in the morning and gradually falling during the day, to become normal or almost normal in the evening (Fig. 2).

Apart from the fever, no significant abnormal findings could be detected on clinical examination. Three cases, however, showed early rickets, manifested by craniotabes and/or increased head-sweating (see Table). All the infants were active well-fed babies of average normal weight for their age. Their appetite was good. Only two patients (Cases 6 and 17) were exclusively breast-fed ; the rest were having either artificial or mixed feeding, with or without some solid food. The exact 
calorie intake was not easy to calculate in all the cases, but no major dietetio error was detected, though three patients were found to have excess cereals added to their milk, two were getting their full-cream milk in one and a half times the usual concentration, and two were having 10 to $25 \mathrm{~g}$. of Casilan daily in their milk.

The investigations, carried out in all cases, did not reveal any significant abnormality. These investigations included: a complete blood picture, blood culture, Widal test, blood Kahn, blood urea, serum electrolytes, $\mathrm{CO}_{2}$-combining power, erythrocyte sedimentation rate, tuberculin test, $x$-ray examination of the chest, urine analysis and culture, and routine stool examination.

In view of (1) the prolonged duration of the fever, (2) the reversed diurnal temperature pattern, in contradistinction to that observed in other febrile illnesses, (3) the absence of any other consistent abnormal clinical or laboratory findings, and (4) the failure to respond to various kinds of drugs, the diagnosis of "nocturnal" thirst fever was considered. It was then

\begin{tabular}{|c|c|c|c|c|c|c|c|}
\hline \multicolumn{5}{|c|}{ Analysis of 17 Cases of Nocturnal } & \multicolumn{3}{|c|}{ Fever in Infants in Kuwait } \\
\hline $\begin{array}{l}\text { Case } \\
\text { No. }\end{array}$ & $\begin{array}{c}\text { Age } \\
\text { in } \\
\text { Months }\end{array}$ & Sex & $\begin{array}{l}\text { Weight } \\
\text { in } \\
\text { kg. }\end{array}$ & $\begin{array}{c}\text { Duration } \\
\text { of } \\
\text { Fever } \\
\text { in Days }\end{array}$ & $\begin{array}{c}\text { Month } \\
\text { of } \\
\text { Onset }\end{array}$ & $\begin{array}{l}\text { Approx- } \\
\text { imate } \\
\text { Daily } \\
\text { Fluid } \\
\text { Intake } \\
\text { (ml./kg. } \\
\text { Body } \\
\text { Weight) }\end{array}$ & Remarks \\
\hline$\frac{1}{2}$ & $\begin{array}{l}5 \\
4\end{array}$ & $\begin{array}{l}\mathbf{M} \\
\mathbf{M}\end{array}$ & $\begin{array}{l}7 \\
6 \cdot 4\end{array}$ & $\begin{array}{l}32 \\
18\end{array}$ & $\begin{array}{c}\text { April } \\
\text { " }\end{array}$ & $\begin{array}{l}130 \\
150\end{array}$ & $\begin{array}{l}\text { Slight leucocytosis } \\
\text { Craniotabes and in- } \\
\text { creased head- } \\
\text { sweating }\end{array}$ \\
\hline $\begin{array}{l}3 \\
4\end{array}$ & $\begin{array}{l}4 \\
9\end{array}$ & $\underset{\mathbf{M}}{\mathbf{F}}$ & $\begin{array}{l}7 \\
8 \cdot 1\end{array}$ & $\begin{array}{l}14 \\
22\end{array}$ & $\begin{array}{c}\text { May } \\
\text { " }\end{array}$ & $\begin{array}{l}125 \\
120\end{array}$ & $\begin{array}{l}\text { Excess cereals added } \\
\text { to milk }\end{array}$ \\
\hline 5 & 6 & $\mathbf{F}$ & 6.9 & 42 & " & 130 & $\begin{array}{l}\text { Thick rice-water } \\
\text { used in prepara- } \\
\text { tion of milk for- } \\
\text { mula }\end{array}$ \\
\hline 6 & 3t & $\mathbf{M}$ & 6 & 16 & June & 140 & $\begin{array}{l}\text { Marked sweating, } \\
\text { especially of head }\end{array}$ \\
\hline $\begin{array}{l}7 \\
8\end{array}$ & $\begin{array}{r}13 \\
7\end{array}$ & $\stackrel{\mathbf{M}}{\mathbf{F}}$ & 10 & $\begin{array}{l}30 \\
25\end{array}$ & July $_{\text {April }}$ & $\begin{array}{l}105 \\
140\end{array}$ & $\begin{array}{l}\text { Put early on solid } \\
\text { food. Getting } \\
\text { only } 360 \mathrm{ml} \text {. milk/ } \\
\text { day }\end{array}$ \\
\hline $\begin{array}{r}9 \\
10\end{array}$ & $\begin{array}{l}4 \\
8\end{array}$ & $\underset{\mathbf{F}}{\mathbf{F}}$ & $\begin{array}{l}5 \cdot 75 \\
8 \cdot 2\end{array}$ & $\begin{array}{l}68 \\
20\end{array}$ & ", & $\begin{array}{l}140 \\
125\end{array}$ & $\begin{array}{l}\text { Craniotabes } \\
\text { Receiving full- } \\
\text { cream milk in } 1 \frac{1}{1} \\
\text { times normal con- } \\
\text { centration }\end{array}$ \\
\hline 11 & 10 & $\mathbf{M}$ & $8 \cdot 75$ & 14 & May & 130 & 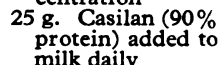 \\
\hline 12 & 61 & $\mathbf{M}$ & $7 \cdot 65$ & 15 & " & 135 & $\begin{array}{l}\text { Excess cereals } \\
\text { added to milk }\end{array}$ \\
\hline $\begin{array}{l}13 \\
14\end{array}$ & 4 & $\underset{\mathbf{F}}{\mathbf{M}}$ & $\begin{array}{l}6 \cdot 2 \\
7 \cdot 4\end{array}$ & $\begin{array}{l}15 \\
50\end{array}$ & $\begin{array}{l}\text { Aug. } \\
\text { April }\end{array}$ & $\begin{array}{l}150 \\
135\end{array}$ & $\begin{array}{l}10 \text { g. Casilan (90\% } \\
\text { protein) added to } \\
\text { milk daily }\end{array}$ \\
\hline 15 & 4 & $\mathbf{M}$ & 6 & 20 & May & 140 & $\begin{array}{l}\text { Receiving full- } \\
\text { cream milk in } 11 \\
\text { times normal } \\
\text { concentration }\end{array}$ \\
\hline 16 & 5 & $\mathbf{M}$ & 7 & 30 & " & 125 & $\begin{array}{l}\text { Craniotabes and in- } \\
\text { creased head- } \\
\text { sweating }\end{array}$ \\
\hline 17 & 3 & $\mathbf{F}$ & $5 \cdot 4$ & 12 & ", & 145 & \\
\hline
\end{tabular}

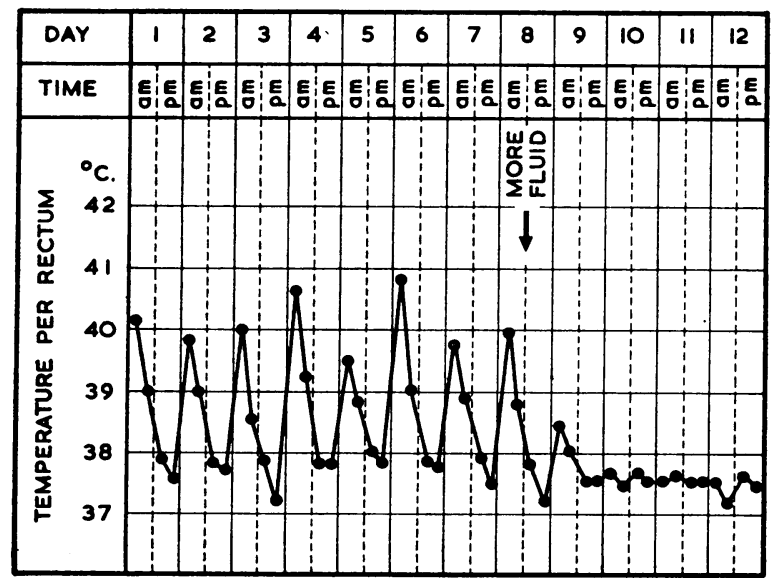
Fig. 2.-Part of temperature chart of Case 10, before and
after administration of more fluids. confirmed by the rapid fall of the temperature within 24 to 36 hours after administration of more fluids, all medicines having been discontinued. Each infant was given an extra amount of fluid, ranging from 400 to $750 \mathrm{ml}$./day, in the form of water and dilute juices. The mothers were instructed to continue giving these fluids all through the summer, and were advised concerning the dietary errors discovered.

\section{Discussion}

From the analysis of the above 17 cases of thirst fever some interesting observations were made. Fourteen presented in the early summer months (April and May) but only three in June, July, and August, which are in fact the hottest months of summer in Kuwait. This may be explained by the higher relative humidity in early summer compared with midsummer (Fig. 3), and the fact that in the very hot months the people either use air-conditioning or leave the country on vacation. The possibility of gradual body-adaptation taking place is worth pursuing.

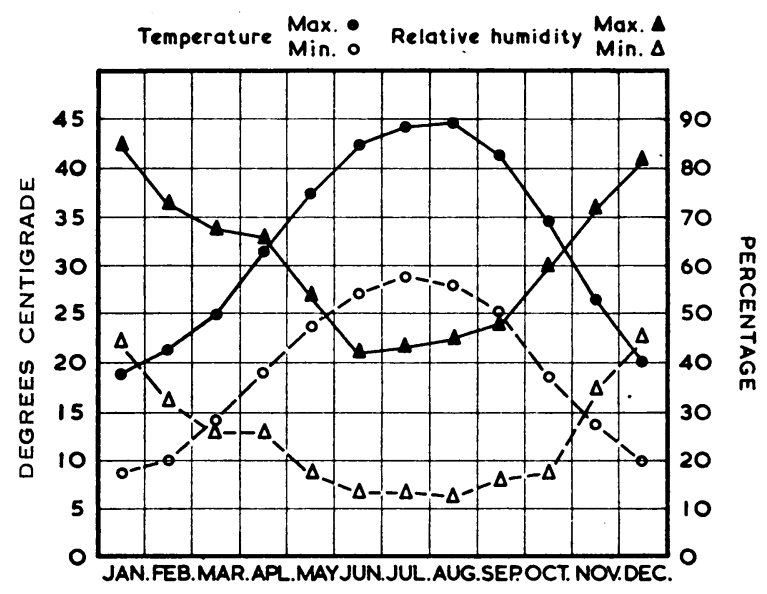

FIG. 3.- Monthly averages of maximum and minimum shade temperature and relative humidity in the State of Kuwait (1954-63).

The age distribution merits consideration; with one exception, no patients were below the age of 3 months or above the age of 10 months. This may be due to the fact that infants 3 to 10 months old require more water per kilogram of body weight daily than younger or older infants.

The condition affects only healthy infants. The 17 patients studied were of average or above average weight for their age. Thirst fever was not observed in any marasmic infants. This may be due to the fact that marasmic babies can withstand water-deprivation better than healthy ones.

Almost all these infants were found to be receiving their proper daily fluid requirements, if not more (see Table), and yet they developed thirst fever of a particular pattern. The fever may be explained by a state of relative water-insufficiency initiated by the hot humid weather and helped by other factors. These factors included: high calorie or protein intake, early rickets with increased sweating, and, finally, the fact that all the infants had their last feed between 6 and 10 p.m., after which time they received no fluids until the next morning. This latter observation may also explain the peculiar morning pattern of the fever. The relative water lack seems to develop during the night; thus the temperature is highest early in the morning. During the day the infants take enough fluids to keep them just hydrated and afebrile. Finally, it is interesting to note that this "nocturnal" thirst fever is quite uncommon among the Kuwaiti infants (only one case out of 17). Whether the racial factor or the individual adaptation plays a part in this low incidence is uncertain. A possible explanation, however, is the fact that most Kuwaiti mothers 
are in the habit of giving extra fluids to their infants right from birth.

\section{Summary}

Seventeen cases of " nocturnal" thirst fever in infants aged 3 to 10 months are described. The only presenting symptom was fever with a characteristic temperature pattern, being very high in the morning and gradually dropping to normal towards the evening. This particular temperature pattern is diagnostic. It helps in the early administration of the proper treatment-extra fluids-without recourse to unnecessary drugs or tedious investigations.
I wish to thank Dr. R. Aziz, Dr. A. Mirshak, Dr. M. El-Sharif, Dr. Aboul-Naga, and Mrs. B. El-Kassim for their great help and co-operation.

\section{REFERENCES}

Choremis, K., Danelatou, C., Maounis, F., Basti, B., Lapatsanis, P., and Kiossoglou, K. (1959) Helv. paediat. Acta, 14, 44.

Finkelstein, H. (1938). Sauglingskrankheiten, p. 212. Elsevier Publish-

Hill, F. S. (1954). Practical Fluid Therapy in Paediatrics. Saunders, Philadelphia.

Holliday, M. A., and Segar, W. E. (1957). Amer. F. Physiol., 191, 610 Levesque, J., and Bastin,-R. (1949). Encyclopédie Médico-Ćhirurgicale Pédiatrie, 2nd ed., 4042, 7-10.

\section{Medical Memoranda}

\section{Phenindione-induced Haemorrhagic Ulcerative Colitis}

Brit. med. F., 1966, 1, 588

Adverse reactions to phenindione are not uncommon. Perkins (1962) reviewed 133 reported and three personal cases. The most common complication was a rash (100 cases); fever ( 34 cases) and diarrhoea (20 cases) also occurred frequently.

In reported cases the onset of diarrhoea, when specified, varied from one week (Tait, 1960) to three and a half months (Perkins, 1962) after the start of treatment. Usually the diarrhoea was mild, but sometimes it increased in severity if phenindione was continued. One patient developed frank steatorrhoea (Juel-Jensen, 1959). A mild latent steatorrhoea may have been present in this patient, as he excreted $10.8 \mathrm{~g}$. of faecal fat in 24 hours after recovery. This patient developed dysentery-like stools with blood and mucus five days after starting phenindione on a subsequent occasion.

We record details of two patients with haemorrhagic ulcerative colitis, one occurring seven days, the other two days, after the start of a first course of phenindione. In neither case was there evidence of any underlying bowel disorder, nor was there any history of previous drug hypersensitivity.

\section{CASE 1}

A man aged 64 had two attacks of transient right hemiparesis He was admitted to hospital on 28 January 1960 after the second episode. On 30 January he was started on phenindione $50 \mathrm{mg}$. twice daily. His bowels were opened once daily until 6 February, when he passed bright blood in his stools. He had never had any bowel symptoms before. His one-stage prothrombin time was 34 sec., control $13 \mathrm{sec}$. Later that day he collapsed with severe rectal bleeding, which persisted. He was given vitamin $K_{1}$ by injection and transfused with a total of 15 pints (8 litres) of blood. He continued to pass small quantities of blood. On 7 February he suddenly collapsed and died with a further severe haemorrhage.

A post-mortem examination was performed by Dr. R. I. K. Elliott. There was blood-stained fluid in the peritoneum. The colon was distended with blood and the colonic mucosa showed multiple, punched-out, circular ulcers. Some penetrated deeply and almost perforated the colon.

\section{CASE 2}

A man aged 64 was admitted to hospital on 8 November 1964 af wer a myocardial infarction. He had mild diabetes mellitus controlled by diet. He was started on phenindione. Thirty-six hours later, after a total of $200 \mathrm{mg}$. phenindione, he passed a loose stool containing fresh blood and mucus. The one-stage (Quick) prothrombin time was $24 \mathrm{sec}$., control $12 \mathrm{sec}$. (16.5\%). Sigmoidoscopy revealed a granular red congested mucous membrane, which bled on contact. The appearance was identical with that seen in ulcerative colitis. A rectal biopsy showed dilated blood-vessels with a dense cellular infiltration, mainly with polymorphs (Dr. R. I. K. Elliott).

Phenindione was stopped, and he was treated with codeine phosphate and a low-residue diet. He continued to pass blood and mucus in decreasing amounts for 48 hours, after which his stools became normal. A patch test to phenindione was negative. On 20 November 1964 he developed thrombophlebitis. He was treated with warfarin without side-effects.

\section{COMMENT}

Both these patients developed acute ulcerative colitis shortly after being given phenindione. The first patient died from recurrent massive haemorrhage and could only have been saved by total colectomy. The second patient recovered without specific treatment when phenindione was stopped. This patient resembled the man described by Juel-Jensen (1959), who also recovered when phenindione was stopped, except that our patient had never taken phenindione before.

This acute type of reaction seems to be uncommon. Most cases of diarrhoea due to phenindione are mild and do not progress to ulcerative colitis.

This report adds to the list of fatal reactions to phenindione. Though there have been fewer reports of side-effects from other oral anticoagulants, it cannot be concluded that they are safer than phenindione unless it is also known how many patients have received each type of drug.

We wish to thank Dr. W. A. Bourne for permission to report the second case.

A. R. TANSER,* M.B., M.R.C.P., Senior Medical Registrar, Royal Sussex County Hospital.

E. C. B. KEAT, M.D., M.R.C.P., Consultant Physician, Royal Sussex County Hospital.

* Present address: King's College Hospital, London. 